\title{
Planning For Baruipur District Headquarters - A Future Growth Node in the Kolkata Metropolitan Area By 2025
}

\author{
Sanjukta Ghosh \\ (Department of Geography, University of Calcutta, India)
}

\begin{abstract}
Baruipur is a subdivision of the district of the south 24 parganas situated on the banks of the tolly canal at the crossing of the diamond harbor and lakshmikantapur between Kolkata and the sunder bans .Recently the Government of the West Bengal has decided to shift the present district Headquarters from Alipur in Kolkata city core to Baruipur which is located in the suburb area of South 24 Parganas. Further there has also been a strategic plan for making Baruipur the Metro Centre by 2025 which has been included in the Vision 2025: A perspective plan of Kolkata Metropolitan Area published in 2005. The main focus of this paper is to discuss the problems of the region and to provide way outs of development in near future through focusing on area of affordable shelter, sustainable development and traffic management.
\end{abstract}

Keywords: Development, Headquarters, Metro center, Planning, Suburb

\section{Introduction}

The geographical location is $20^{\circ} 30^{\prime}$ latitude in the north and $88^{\circ} 25^{\prime}$ longitude east. Baruipur became a subdivision in 1858. The land is bounded by sonarpur in the north, by jainagar in the south, east canning and west by bishnupur. During British days it was well known for its indigo plantation. Baruipur Municipality is located in the extreme southern side of Kolkata Metropolitan Area line has connected this municipality with Kolkata and the southern part of the south 24 parganas . Garia - Baruipur Road or Kulpi Road is one of the major roads which have connected the area with Kolkata and the North 24 parganas through Eastern Metropolitan By Pass. Other major roads like Madarhat Road, Dhabdhabi Road, and Canning Road connected the area with eastern part while Amtala Road has linked it with the adjacent western part.People of the South twenty four parganas have been demanding for a long time to relocate the district headquarter from Alipur, Kolkata. The present location of Alipur, Kolkata is not only inconvenient to the people of the district due to its eccentric location and distance factor; it also puts undesired pressure and conflict to Kolkata city proper. Hence, relocation of the District HQ is very much necessary from Alipur, Kolkata. Further there has been uncontrolled urbanization in the south eastern part of KMA, which is intensified due to recent extension of metro rail and E.M bypass. This has resulted in consuming valuable agricultural land and the formation of low density leap frog development leading to low revenue earning and limiting the scope for future planned development.

The main objectives of this paper are first to relocate district headquarters and its associated activities at new location for efficient functioning. In addition to achieve the following objectives:

- To understand the overall structure of the area.

- To study the general problems of the area.

- To evolve a plan methodology for developing the node after study.

- To suggest developmental strategy for sustainable Land Use.

- To provide way outs of development for future.

- To focus on areas of sustainable development, affordable shelter and efficient transport system cum traffic management.

\section{Regional Context And Demographic Pattern Of The Area}

Total population of the Baruipur Municipality as recorded in 2001 census is 44964 . The average annual growth rate is nearly $19.68 \%$. The gross density of the population is $49 \mathrm{P} / \mathrm{Ha}$. Among this, $50.9 \%$ of the population are comprises of male and $49.1 \%$ is female. From the figure we can derive that the majority of the population is in the age group of 26-59years which is about $57 \%$ of the total population but on the other hand this figure also depicts that the rest $43 \%$ of the population is not in the work force age group and also the fact that a considerable percentage of population also exists in the age group of 11-25 which will necessitate the requirement of good education and training facilities in the form of schools and colleges and also planning of good infrastructure for the better futuristic possibilities of new generation. Child Health needs to be taken well care as there is a considerable percentage of minor population in the municipal area. This also means that the settlements are newly developing are need to be matched with the migration analysis of the municipal area. 
2.1 Sex ratio The Ideal ration of Male: Female should be 1: 0.9. If calculated in percentage of both should be varying as 50\%:49\% or nearby range. The figure shows that male: female ratio in percentage $=50.9 \%: 49.1 \%$ which is in the normal range. So the number of female population per 1000male is 964 .

2.2 Population Density It is calculated through the choropleth map where it is seen that wards no 2, 3, 13 and 14have a high density of population above 8675 and areas of wards 4, 5,7,8,9, 11have a low population density of below 6115 .

Table 1 Decadal Variation Decadal Growth of Baruipur Municipality.

\begin{tabular}{|l|l|l|l|}
\hline Year & Persons/population & Decadal variation & Percentage of variation \\
\hline 1901 & 4217 & - & - \\
\hline 1911 & 6375 & +2158 & +51.17 \\
\hline 1921 & 5114 & -1261 & -19.78 \\
\hline 1931 & 6483 & +1369 & +26.77 \\
\hline 1941 & 7130 & +647 & +9.98 \\
\hline 1951 & 9238 & +2108 & +29.57 \\
\hline 1961 & 13608 & +4370 & +47.30 \\
\hline 1971 & 20501 & +6893 & +50.65 \\
\hline 1981 & 27081 & +6893 & +50.65 \\
\hline 1991 & 37659 & +6580 & +32.10 \\
\hline 2001 & 44694 & +7305 & +19.40 \\
\hline
\end{tabular}

(Source: Baruipur Municipality)

The Percentage of Minor Population is $11.6 \%$. Hence it is revealed that Baruipur consists of a large number of migrant populations especially from the other areas of south 24 parganas namely namkhana, lashmikantapur and interiors of sunder bans. Household Population of each ward is also calculated which depicts ward 1,2,11 13 and 14 are huge areas of attraction for people to reside.

\section{Land Use Pattern}

3.1 Characteristics of soil and its topography The general ground pattern of baruipur is by large composed of alluvial soil. Despite the fact that the soil is basically composed of alluvium borne by river water due to variation in the river flow at different time of the season, deposition of alluvium over land varies from place to place form wide scale undulation particularly on the river side. The topography is more or less flat.

Table 2 Existing Land Use percentage of the municipality:-

\begin{tabular}{|l|l|l|l|}
\hline Sl no & Name of the Item & Area Total & Percentage \\
\hline 1 & Residential & $6758897.00 \mathrm{sq} \mathrm{m}$ & $74.508 \%$ \\
\hline 2 & Commercial & $145455.00 \mathrm{sq} \mathrm{m}$ & $1.603 \%$ \\
\hline 3 & Club & $47189.00 \mathrm{sq} \mathrm{m}$ & $0.520 \%$ \\
\hline 4 & Religious & $63584.00 \mathrm{sq} \mathrm{m}$ & $0.700 \%$ \\
\hline 5 & Open spaces & $308327.00 \mathrm{sq} \mathrm{m}$ & $3.399 \%$ \\
\hline 6 & Parks & $71816.00 \mathrm{sq} \mathrm{m}$ & $0.791 \%$ \\
\hline 7 & Orchards & $804099.00 \mathrm{sq} \mathrm{m}$ & $8.863 \%$ \\
\hline 8 & Educational Area & $23539.00 \mathrm{sq} \mathrm{m}$ & $0.260 \%$ \\
\hline 9 & Pub and semi pub & $117419.00 \mathrm{sq} \mathrm{m}$ & $1.294 \%$ \\
\hline 10 & Water body & $731453.00 \mathrm{sq} \mathrm{m}$ & $8.062 \%$ \\
\hline Total & & $9071778.00 \mathrm{sq} \mathrm{m}$ & $100.00 \%$ \\
\hline
\end{tabular}

(Source Baruipur Municipality)

\subsection{Land Use Pattern (ward wise)}

Ward wise land use pattern shows that ward no -11 has highest concentrations of residential units as high as $88.024 \%$ of overall area against $74.508 \%$ in municipal area. The percentage of area break up is highest for commercial development of $18.813 \%$ against 1.603 only in the municipal area. It reveals that the commercial units in the entire Baruipur area located mostly in ward no - 13 only. Educational institutions occupy maximum area of $1.243 \%$ against municipal area standard of $0.26 \%$. Water bodies occupy maximum area of $14.39 \%$ in ward no- 13 against municipal figure of $8.602 \%$ only. These water bodies need to be preserved carefully. Open spaces is maximum $3.04 \%$ in ward no- 1 against around $3.4 \%$ in municipal area. 
Trends of land use pattern have been shown through time series analysis from 1951 - 2011 in commercial, residential, water bodies, orchards and open spaces respectively which reveals again the havoc increase in the residential area and abrupt decrease of open spaces .

On the other hand ward wise percentage of land use component (open space) has been shown which reveals maximum concentration of it in ward no 1 and 2 respectively.

Again land utilization on the basis of Direction and size are calculated which shows the parameters namely orchards, commercial, water bodies and residential. As per 2001 data rapid increase of commercial and residential area indicates a steady development of the area .It is worth mentioning that average annual population growth of west Bengal is 3.64 percent over decade against 1.53percent of India . The ratio of population to land of the state is 0.13 against country 0.36 .This demands for a careful, rational and scientific approach, when the planning intervention is made.

An analysis on land holding capacity emphasizes on the creation of new settlements with employment opportunity. In vision 2025 there is proposals to develop five major Trans metro growth centre's Baruipur is one of them. Hence proposals of district H.Q and township is a part of the comprehensive plan program. South 24parganas district comprises 5 subdivisions (Diamond harbor, Canning, Baruipur, Alipur and Kakdwip), 29 blocks and 7 municipal towns. It's a complex district diversified from Kolkata metro to sunder bans with vast marshy lands. It has huge resource base for agriculture and forest. With creation of physical infrastructure like roads, railways, bridges, water supply power by government in the region the ground is ready for development. The site for district headquarters and townships is located at the Baruipur block in south 24 parganas is $25 \mathrm{~km}$ away from the CBD (BBD BAG AREA) of Kolkata. KMDA initially delineated eight mouzas under Baruipur and Sonarpur PS for this purpose. However five mouzas have been included from Bishnupur and Baruipur PS have been included. The site is about $4 \mathrm{~km}$ away from Baruipur - Amtala Road connecting NH 117 (Diamond Harbor Road). Railway connectivity on sealdah - diamond harbor route is available nearby

The Roads are moderately developed in the region of Baruipur. Some of the major roads linking the area with other region viz. Garia - Baruipur Road / Kulpi Road, Bantala Road , Kheyadaha road, Narayanpur - Bodra Road, Chakraberia - Baruipur Road, Baruipur - Canning Road, Baruipur - Amtala Road, Madarhat Road etc. The Eastern Metropolitan Bypass connecting the eastern fringes of Kolkata including Salt lakes townships and the newly growing Rajarhat Township also serves the area.

\section{Traffic Management And Flow Of Vehicles}

4.1 Road Transport Modes The town provides with the facilities of almost all of the surface transport units right from the ethnic bullock carts to the modern railway EMU services. The buses, the trekkers, the auto rickshaws form the major inter and intra city public transport services. Taxis have also gained a reasonable popularity in the area. Private cars have also added to the dignity to the citizens'. The most popular short distance public transport units are the cycle rickshaws, individual motorbikes and bicycles have almost infested the entire township. Hand driven carts and cycle vans are the most common carriers of goods traffic. The Lorries, trucks and three wheeler tempos also do make a considerable contribution in the goods transport area.

4.2 Railway system Baruipur is connected with remaining part of the hinterland by railway but the facilities are not at all adequate and needs to be increased and upgraded to cater for the increasing travel demands. The suburban rail network of the sealdah south section of the eastern railways passes through the area connecting Canning - Diamond Harbor and Kakdwip. Baruipur rail station connects the suburban railway network. The suburban rail services in the area support the major transit movement in the area. It also caters for the daily movement of the majority of vegetables and fruits to Kolkata and other areas.

Table 3 Peak periods of Train and passengers

\begin{tabular}{|l|l|}
\hline Morning peak period & Evening peak period \\
\hline $\begin{array}{l}\text { Average number of passengers terminating per } \\
\text { hour 2580 }\end{array}$ & $\begin{array}{l}\text { Average number of passengers terminating } \\
\text { per hour -4701 }\end{array}$ \\
\hline $\begin{array}{l}\text { Average number of outgoing passengers per } \\
\text { hour - } 3368\end{array}$ & $\begin{array}{l}\text { Average number of outgoing passengers per } \\
\text { hour-3469 }\end{array}$ \\
\hline Source: Baruipur municipality. & \\
\hline
\end{tabular}

4.3 Other para transit modes Apart from the buses and mini buses the transit modes that operate in the area are auto rickshaws, cycle and cycle vans. There are a number of congested locations in the area where frequent traffic jams occur causing delays and disruptions of the movements of vehicles and transit passengers. The baruipur level crossing particularly causes dislocations of traffic movement. 
Planning for Baruipur District Headquarters - A future growth node in the Kolkata Metropolitan

Table 4 Location of Major Pressure Points of traffic

\begin{tabular}{|l|l|l|l|l|l|}
\hline $\begin{array}{l}\text { Location of } \\
\text { pressure points }\end{array}$ & $\begin{array}{l}\text { Width of roads } \\
\text { (meters) }\end{array}$ & $\begin{array}{l}\text { Designed } \\
\text { passenger car } \\
\text { unit (PCU) }\end{array}$ & $\begin{array}{l}\text { Workable PCU } \\
\text { under } \\
\text { efficiency } \\
\text { factor }\end{array}$ & $\begin{array}{l}\text { PCU } \\
\text { calculated as } \\
\text { per traffic flow }\end{array}$ & $\begin{array}{l}\text { Capacity } \\
\text { Saturation } \\
\text { level. }\end{array}$ \\
\hline $\begin{array}{l}\text { Padmapukur } \\
\text { Crossing }\end{array}$ & 5.8 & 3045 & 2132 & 21332 & Not saturated \\
\hline $\begin{array}{l}\text { Baruipur Rail } \\
\text { Gate }\end{array}$ & 5.3 & 2625 & 1838 & 1957 & Supersaturated \\
\hline Puaratan Bazar & 5.1 & 2625 & 1838 & 871 & $\begin{array}{l}\text { Less than 50\% } \\
\text { utilization }\end{array}$ \\
\hline Puratan Thana & 4.5 & 2362 & 1654 & 541 & Poor utilization \\
\hline
\end{tabular}

(Source - Baruipur Municipality)

It is evident that from the above table that baruipur rail gate being super saturated calls for the widening of the road. Solution to this problem lies in the proposal of flyover. The proposed location of the flyover is only 220 mters away from the centre of baruipur railway station. The matter should be pursued.

\section{Developmental Strategies Of The Area}

Present scenario of the area is turning towards the conceptual frame work of Urban Complex especially in last 5 years in ward no 14 and d 15 respectively. Near railway station Shops are growing at a faster rate with road shortage leading to commotion. Rail market is really a big hub for the local residents and the people. Major houses are pakka houses while major sector of population in the municipal area is active sector population and young generation. There are 700 stand posts while Tap water connection to the houses comprises around 240-280 respectively. Major areas are under the courtesy of deep tube wells and are prone to water borne diseases and arsenic prone diseases. Wards $6,7,8,9,10,11,12,13,14$, and 15 have cast iron pipeline as well as asbestos or cemented pipeline.

5.1 Housing for all In KMA the housing gap is increasing as the annual addition of new unit is about 15,000against the need of 75,000per year Group and plotted housing have been distributed equally distributed with suitable mix of people of different income category. The most existing settlement area has been protected with provision for adequate social and physical infrastructural facilities and is proposed for the densification to accommodate future population.

5.2 Commerce and recreation Commercial facilities shave been provided at different levels with overlapping catchments and inter connected to ensure freedom of choice. Central facilities have been distributed over CBD and sub CBD. CBD accommodating shopping, business retail, entertainment and civic is major economic generator to set the image of the city and act as a magnet to the region. Both provisional malls / multiplex and small shop at different levels are ensured.

5.3 Infrastructural and utility services Water supply in addition to the augmentation of the pipeline water supply alternative source storage in lakes and depressions through rain water harvesting is proposed. Sinking of deeper aquifer based on the deeper tube wells and installation of arsenic removal plants are also proposed.

5.4 Sewerage and drainage facilities include compulsory construction of compost from urban waste and recycle of waste water is proposed with treatment plant at the western part of the township near existing canal. Regional canal at the south connecting Keorapukur Khal and Adi Ganga for Comprehensive regional system is also proposed.

5.5 Solid waste Management As disposal systems of solid wastes, sanitary, landfill with compaction and layer of soil, composting and incineration with primary and secondary combustion are proposed

5.6 Environmental Protection As per government protection act any big township project needs clearance from the government through environmental impact report which will also indicate, measures to save the environment Under the proposal the provision for green barrier between industry and residential area , a forestation , preservation of orchards greenery/ water body are made to prevent pollution. Large water bodies are to act as holding ponds and to receive treated effluent. De siltation of canals, rain water harvesting and treatment of cycle and wastes are the proposals of the governments.

The development process includes company formation, land acquisition, selection of agencies for the development, execution, marketing, finance and management. The most efficient and rational method of development is found through Public -Private - Partnership (PPP). PPP ensures sharing of responsibility, ownerships, service .risk .and reward. This would provide greater benefits like cost- effectiveness, higher productivity, accelerated delivery, custom focus and user changes. 
The proposed project period is 18 years (2007-2025) which is divided into 3 phases. The initiation phase (28\%) will accommodate capital complex with supplementary activities like commercial, buses terminus, and housing and up gradation of existing settlement. With operation of township other land would be included in development (48\%) and maturity (24\%) phase. In respect of salability of developed land $47 \%$ percent would be saleable, 32percent would be non saleable and 21\%towards lease and rent. The phasing is initiated considering least disturbances to locals and proximity to urban centre. Sale price is fixing based on the break even sale and comparative analysis of market.

\section{Conclusions}

All the successful projects have interdependent administrative authority with powers and responsibilities. Hence suitable mix of financing from various sources as basket approach with efficient financial management and innovative resource recovery mechanism would give maximum financial return.

Built on industrial bases and within a Master Plan that incorporates economical and physical aspects locally and regionally, township would be a self sufficient growth node. Private sector contribution cannot be achieved without investment incentives from the government through infrastructure and other facilities. Hence government's commitment is a must.

Long gestation period has been considered since long process involved in development .During the end of each phase of development flexible modification of the plans and policies is a must. An execution of the plan is dependent on the three tier system of national, regional and local plan we have followed the KMA: Vision 2025. Development of the Baruipur Headquarters of the district is a long term plan which is based on the various parameters like social security, civic amenities like proper water supply, garbage disposal, health services , proper sewerage system etc. Infrastructural facilities like equipped hospitals, nursing homes, International schools, colleges etc are very important for the advancement of the area.

Baruipur being the most successful region for future township settlement is widely attracting people especially the middle class people who prefer to settle down in the fringe area which has easy connectivity with the core CBD of Kolkata. Metro services and the extension of metro upto Garia station also acted as a catalyst to this. The Baruipur area is trying to keep the best performance, there lays some gaps which need to be covered up. Being administrative body civic amenities need to be improving especially the huge traffic jams at railway gate crossing and padmapukur area should be taken care off. Spread of awareness about the health to resist diseases from entering the region about the literacy to ensure better jobs prospects, about position of woman in society, could give a better social stability. Proper Planning and enforcement of plans could change the development scenario of the studied - region.

\section{Acknowledgement}

I would like to offer my deepest sense of gratitude to my Professor and Research Supervisor Dr. Kanan Chatterjee of Department of Geography Ballygung Science College, University of Calcutta for giving valuable suggestion and supervising the entire work. Without her help and guidance this dissertation would not have taken its present shape. I offer special thanks to the Urban Planner of the Baruipur Municipality Mr. Subhashis Ghosh land development department of Baruipur Municipality for assisting me in various ways regarding the completion of my article.

\section{Journal Papers:}

\section{References}

[1] D.Chakraborty and S. Chattopadhyay , Planning for the district headquarters township at Baruipur in South Twenty Four Parganas,IIPI Journal 5:1(2008) 48-62

[2] Baruipur Municipal Report 2001, 2011 